\title{
Assessment of the quality of fresh frozen plasma and refrozen thawed fresh frozen plasma - A prospective study at a tertiary care teaching hospital in Chennai
}

\author{
D. Umesh ${ }^{1, *}$, Arumugam $\mathbf{P}^{2}$ \\ ${ }^{1}$ Assistant Professor, ${ }^{2}$ Professor and HOD, ${ }^{1}$ Dept. of Transfusion Medicine \& Blood Bank, ${ }^{2}$ Dept. of Transfusion Medicine, \\ ${ }^{1}$ Rajiv Gandhi Government General Hospital \& Madras Medical College, Chennai, ${ }^{2}$ The Tamilnadu Dr. MGR Medical \\ University, Guindy, Chennai, Tamil Nadu India
}

*Corresponding Author:

Email: drumesh77@gmail.com

Received: $17^{\text {th }}$ October, 2017

Accepted: $31^{\text {st }}$ October, 2017

\begin{abstract}
Introduction: FFP contains the labile as well as stable components of the coagulation, fibrinolytic and complement systems. The use of plasma and its products has increased manifold over the four decades. In blood transfusion service, the primary goal of quality is 'transfusion of safe unit of blood.'

Aim of the Study: To ensure that the prepared fresh frozen plasma (FFP) consistently met the requirements for quality and to find out the potency and possible extension of shelf life of fresh frozen plasma once thawed and refrozen within stipulated period. Materials and Methods: 66 units of FFP prepared by Platelet Rich Plasma (PRP) method were divided into two groups. Group 1 comprised of 33 samples, which were tested on 0 day, last week of $12^{\text {th }}$ month and last week of $18^{\text {th }}$ month. Group 2 comprised of remaining 33 units which were tested on 0 day, thawed and tested on $1^{\text {st }}$ week of $12^{\text {th }}$ month and were again refrozen within 12 hours of thawing. Later, the refrozen units were again retested on the last week of $12^{\text {th }}$ month. All the FFP units were evaluated as per the DGHS Guidelines.

Results: Group 1: The quality of fresh frozen plasma stored at $-30^{\circ} \mathrm{C}$ for 12 months adhered to quality parameters but on extended storage period $\left(-30^{\circ} \mathrm{C}\right.$ for 18 months) showed non-compliance to the standardized quality control. Group 2: Refrozen thawed plasma complied with all quality parameters.

Discussion: Fibrinogen and Factor VIII levels, which were representative of stable and labile factors respectively, were within normal limits in both the study groups when stored at standardized temperature and time, but showed non-compliance to the standardized quality control at extended time. Refrozen thawed plasma retained all coagulation factors. These findings were in concordance with the DGHS Standards and various other studies.

Conclusion: Fresh Frozen Plasma should be used judiciously and if thawed plasma is not used for some reasons, it should not be discarded. The thawed FFP can be refrozen and added up to the inventory and hence, useful to the society.
\end{abstract}

Keywords: Good manufacturing practice, Fresh frozen plasma, Platelet rich plasma, Thawed and refrozen fresh frozen plasma.

\section{Introduction}

In blood transfusion service, the primary goal of quality is 'transfusion of safe unit of blood.' The objective is to ensure availability of a sufficient supply of blood, blood components of high quality with maximum efficacy and minimum risk to both donors and patients. A failure in the quality of blood collected or screening of donated blood unit can be very serious and may result in fatal consequences. As the blood transfusion service provider is a supplier of blood products and at the same time a test laboratory, the quality management system must include good medical practice, good manufacturing practice and good laboratory service, all of which are closely linked. As per the Directorate General of Health Services (DGHS) and American Association of Blood Banks (AABB) Guidelines for Good Manufacturing Practice (GMP), $1 \%$ of all units with minimum of 4 units per month should have to be checked for quality control. ${ }^{1,2}$ As demand is always more than supply, it is imperative to find innovative ways to extend the existing shelf-life of various blood components being used in medical practice.

\section{Review of Literature}

In India, the blood components (Red Blood Cells, Platelets and Fresh Frozen Plasma) are prepared by the widely used platelet rich plasma (PRP) method. Fresh Frozen Plasma (FFP) is the plasma separated from whole blood and placed in the freezer within 8 hours of whole blood collection and if longer than 8 hours but less than 24 hours, they are called frozen plasma (FP). Fresh Frozen Plasma (FFP) contains the labile as well as stable factors of the coagulation, fibrinolytic and complement systems. FFP has a shelf life of 12 months while stored at $-18^{\circ} \mathrm{C}$ or colder. According to AABB Standards, FFP that is stored at $-65^{\circ} \mathrm{C}$ may be stored for 7 years. Once thawed, FFP should be administered as soon as possible and in any event; within 12 hours if kept at $2-6{ }^{\circ} \mathrm{C} .{ }^{2}$ FFP that is not used for transfusion can be used for fractionation to manufacture plasma derivatives.

To ensure proper quality, according to DGHS and World Health Organisation (WHO) guidelines the prepared FFP should comply with the following parameters within the acceptable range of values given against each one of them as depicted in table no.1. 
The council of Europe guidelines for quality assurance of blood components also defines that the residual cells - Red blood cells and White blood cells in FFP should be less than $6.0 \times 10^{9}$ per litre and $0.1 \mathrm{X}$ $10^{9}$ per litre. $^{4}$

The Australian \& New Zealand Society of Blood Transfusion Limited framework on preparation ,storage and use of extended life plasma demonstrated microbiological sterility of thawed plasma stored for five days at $2-6^{\circ} \mathrm{c} .{ }^{5}$

Ofira Ben-Tal et al in their study on twenty units of FFP concluded that Vitamin K-dependent coagulation factors and fibrinogen levels remained stable upon repeated freezing and thawing. ${ }^{6}$

Lamboo et al in their study on coagulation levels of thawed Fresh Frozen Plasma (FFP) stored at RT for $6 \mathrm{~h}$ or at $4{ }^{\circ} \mathrm{C}$ for 2 weeks was sufficient to support for adequate haemostasis, except for patients with a known deficiency for FVIII. ${ }^{7}$

Hossin Timori Naghadeh et al study on thawed plasma stored at 1 to $6^{\circ} \mathrm{C}$ for 5days found that the changes in the range of coagulation factors, prothrombin time and activated partial thromboplastin time over the 5 days storage period were statistically significant, but the values remained within the haemostatic range. ${ }^{8}$

Dzik et al reported that the coagulation properties of FFP units that were refrozen and then rethawed were always within the normal range and reiterated that refreezing FFP may eventually prove useful for rare donor, autologous and massive transfusion programs. ${ }^{9}$

\section{Aim of the Study}

1. To ensure that frozen fresh plasma prepared, consistently meet requirements for quality, safety, identity, potency and purity.

2. To find out the possible extension of shelf-life of frozen fresh plasma once thawed and refrozen within stipulated time period retains potent coagulation factors.

\section{Methodology}

The fresh frozen plasma prepared by platelet rich plasma method, in the department of transfusion medicine, The TN Dr. M.G.R. Medical University was evaluated for quality as per the DGHS ${ }^{1}$ and WHO Guidelines. ${ }^{3} \mathrm{~A}$ total number of 66 samples was studied. Out of the 66 samples of Fresh Frozen Plasma (FFP), Group-1 comprised of 33 samples of FFP tested on day 0 , last week of $12^{\text {th }}$ month and last week of $18^{\text {th }}$ month. Group-2 comprised of remaining 33 units, which were tested on day 0 , thawed and tested at $1^{\text {st }}$ week of $12^{\text {th }}$ month and were again refrozen within 12 hours of thawing. The refrozen units were retested in the last week of $12^{\text {th }}$ month. FFP units were evaluated for the following quality parameters: Volume, Prothrombin Time (PT), Activated Partial Thromboplastin Time (APTT), factor VIII, fibrinogen, RBC count, WBC count and bacterial culture.

\section{Methods of Evaluation}

1. Volume of Fresh Frozen Plasma were calculated by using following formula:

Collected Vol. $(\mathrm{ml})=\frac{[\text { Weight of bag }+ \text { Plasma }(\mathrm{gm})]-\text { Weight of the empty bag }(\mathrm{gm})}{\text { Specific gravity of Plasma }}$

2. WBC Count and RBC Count were evaluated by using automated blood cell counter (MEDONIC Blood Cell Counter CA 620 Loke, Merck) as per manufacturer's instructions.

3. Fibrinogen, PT, APTT and F VIII were assayed by using Coagulometer (Coastat - 1 Coagulometer, Tulip) as per manufacturer's instructions.

4. Sterility check of the components was done by culture in biphasic medium.

\section{Results}

During the study period, 66 Units of Fresh Frozen Plasma (FFP) were divided in to two groups: Group-1 and Group-2 and were evaluated as per DGHS and WHO standards.

1. The volume of FFPs in Group-1 and Group-2 were in accordance to the standard requirements of DGHS and WHO criteria.
2. PT and APTT on day 0 and last week of $12^{\text {th }}$ month in group-1 and day 0 and 1 st week of $12^{\text {th }}$ month in group-2 were within normal range compared to other studies. PT and APTT of the refrozen thawed plasma in Group-2 were slightly prolonged and can be considered normal in comparison to other studies. However, PT and APTT at $18^{\text {th }}$ month FFP in Group-1 were undoubtedly prolonged.

3. Fibrinogen level and factor VIII on day 0 and last week of $12^{\text {th }}$ month of Group- 1 and day 0 and $1^{\text {st }}$ week of $12^{\text {th }}$ month of Group-2 was within normal range as per DGHS norms ${ }^{1}$ and WHO standards. Fibrinogen level and Factor VIII on refrozen thawed plasma at the last week of $12^{\text {th }}$ month in Group-2 was within normal range as per DGHS norms and WHO standards. However, fibrinogen level and factor VIII level was significantly decreased in the FFP stored at 18 months in Group1.

4. RBCs and WBCs present on the first day of processing were within normal range as per council 
of Europe standards and were undetectable on last week of $12^{\text {th }}$ month and last week of $18^{\text {th }}$ month in Group-1 and $1^{\text {st }}$ week of $12^{\text {th }}$ month and last week of $12^{\text {th }}$ month in Group-2.

5. Bacterial culture on all FFP samples from both the groups showed no growth and was similar to the study conducted by The Australian \& New Zealand Society of Blood Transfusion Limited.

6. Table 1 shows the comparison of our study with other studies Worldwide.

Table 1: Comparison of our study with other studies worldwide

\begin{tabular}{|c|c|c|c|c|c|c|c|c|}
\hline Parameter & DGHS $^{1}$ & $\begin{array}{c}\text { Council of } \\
\text { Europe }^{4}\end{array}$ & $\begin{array}{c}\text { WHO } \\
\text { Guidelines }^{3}\end{array}$ & $\begin{array}{c}\text { HT } \\
\text { Naghadeh et } \\
\text { al study } \\
\end{array}$ & $\begin{array}{c}\text { Ofira Ben - } \\
\text { Tal et al., } \\
\text { study }^{6}\end{array}$ & $\begin{array}{c}\text { Lamboo } \\
\text { et al study }{ }^{7}\end{array}$ & $\begin{array}{c}\text { Present } \\
\text { study (Gp- } \\
\text { 1) }\end{array}$ & $\begin{array}{c}\text { Present } \\
\text { study }(\text { Gp-2) }\end{array}$ \\
\hline Volume & $200-220 \mathrm{ml}$ & $\begin{array}{c}\text { Stated volume } \\
\pm 10 \% \\
(200-240 \mathrm{ml})\end{array}$ & $200-300 \mathrm{ml}$ & -- & -- & -- & $211 \pm 17$ & $208 \pm 20$ \\
\hline $\begin{array}{l}\text { Stable } \\
\text { coagulation } \\
\text { factors }\end{array}$ & $\begin{array}{l}200 \text { units } \\
\text { of each } \\
\text { factor }\end{array}$ & --- & $\begin{array}{l}1 \mathrm{unit} / \mathrm{ml} \text { of } \\
\text { each factor }\end{array}$ & -- & -- & -- & -- & -- \\
\hline \multirow[t]{3}{*}{ Factor VIII } & \multirow{3}{*}{$\begin{array}{c}0.7 \text { units } \\
/ \mathrm{ml}\end{array}$} & \multirow[t]{3}{*}{$\geq 70 \%$} & \multirow[t]{3}{*}{$\geq 70 \%$} & \multirow[t]{3}{*}{$79.4 \%$} & \multirow[t]{3}{*}{---} & \multirow[t]{3}{*}{--} & $98 \%^{a}$ & $97 \%^{a}$ \\
\hline & & & & & & & $97 \%^{b}$ & $96 \%{ }^{d}$ \\
\hline & & & & & & & $11 \%^{\mathrm{c}}$ & $91 \%^{\mathrm{e}}$ \\
\hline \multirow[t]{3}{*}{ Fibrinogen } & \multirow{3}{*}{$\begin{array}{c}200-400 \\
\mathrm{mg}\end{array}$} & \multirow[t]{3}{*}{---} & \multirow[t]{3}{*}{---} & \multirow[t]{3}{*}{---} & $296 \pm 49 . \$$ & \multirow[t]{3}{*}{---} & $318.94^{\mathrm{a}}$ & $320.00^{\mathrm{a}}$ \\
\hline & & & & & $292 \pm 48^{\$ \$}$ & & $300.70^{\mathrm{b}}$ & $299.27^{\mathrm{d}}$ \\
\hline & & & & & & & $134.85^{\mathrm{c}}$ & $278.24^{\mathrm{e}}$ \\
\hline \multirow[t]{3}{*}{ PT(Secs) } & \multirow[t]{3}{*}{---} & \multirow[t]{3}{*}{---} & \multirow[t]{3}{*}{---} & \multirow[t]{3}{*}{$13.6 \pm 0.8$} & \multirow[t]{3}{*}{---} & \multirow[t]{3}{*}{$11.7(0.5)^{\#}$} & $13.24^{\mathrm{a}}$ & $12.85^{\mathrm{a}}$ \\
\hline & & & & & & & $13.42^{b}$ & $13.73^{d}$ \\
\hline & & & & & & & $19.24^{\mathrm{c}}$ & $14.55^{\mathrm{e}}$ \\
\hline \multirow{3}{*}{$\begin{array}{l}\text { APTT } \\
(\text { Secs })\end{array}$} & \multirow[t]{3}{*}{---} & \multirow[t]{3}{*}{---} & \multirow[t]{3}{*}{---} & \multirow[t]{3}{*}{$34.3 \pm 3.7$} & \multirow[t]{3}{*}{---} & \multirow[t]{3}{*}{$26.6(1.0)^{\# \#}$} & $30.18^{\mathrm{a}}$ & $30.06^{\mathrm{a}}$ \\
\hline & & & & & & & $31.52^{b}$ & $31.42^{\mathrm{d}}$ \\
\hline & & & & & & & $37.42^{\mathrm{c}}$ & $32.67^{\mathrm{e}}$ \\
\hline \multirow{3}{*}{$\begin{array}{l}\text { RBC count } \\
\left(\times 10^{9} / \mathrm{L}\right)\end{array}$} & --- & $<6.0$ & --- & --- & --- & --- & $3.92^{\mathrm{a}}$ & $4.21^{\mathrm{a}}$ \\
\hline & & & & & & & Undetected $^{\mathrm{b}}$ & Undetected $^{\mathrm{d}}$ \\
\hline & & & & & & & Undetected $^{\mathrm{c}}$ & Undetected $^{\mathrm{e}}$ \\
\hline \multirow{3}{*}{$\begin{array}{l}\text { WBC Count } \\
\left(\times 10^{9} / \mathrm{L}\right)\end{array}$} & --- & $<0.1$ & --- & --- & --- & --- & $0.093^{\mathrm{a}}$ & $0.097^{\mathrm{a}}$ \\
\hline & & & & & & & Undetected $^{\mathrm{b}}$ & Undetected $^{\mathrm{d}}$ \\
\hline & & & & & & & Undetected $^{\mathrm{c}}$ & Undetected $^{\mathrm{e}}$ \\
\hline \multirow{3}{*}{$\begin{array}{l}\text { Bacterial } \\
\text { Culture* }\end{array}$} & --- & --- & --- & --- & --- & --- & No Growth ${ }^{\mathrm{a}}$ & No Growth $^{a}$ \\
\hline & & & & & & & No Growth ${ }^{b}$ & No Growth ${ }^{\mathrm{d}}$ \\
\hline & & & & & & & No Growth ${ }^{\mathrm{c}}$ & No Growth $^{\mathrm{e}}$ \\
\hline
\end{tabular}

$\mathrm{a}=\mathrm{O}$ day, $\mathrm{b}=$ Last week of $12^{\text {th }}$ month, $\mathrm{c}=$ Last week of $18^{\text {th }}$ month, $\mathrm{d}=$ first week of $12^{\text {th }}$ month, $\mathrm{e}=$ Last week of $12^{\text {th }}$ month.

\$ First week of $9^{\text {th }}$ month $=296 \pm 49, \$ \$$ second week of $9^{\text {th }}$ month on refrozen thawed plasma $=292 \pm 48$.

\#Baseline value Mean $(\mathrm{SD})=11.7(0.5)$, Prolonged gradually upon storage at RT for $6 \mathrm{hrs}$ and $2 \mathrm{wks}$ at $4{ }^{\circ} \mathrm{C}$, however sufficient to support haemostasis

\#\#Baseline value Mean (SD)=26.6 (1.0) ,Prolonged gradually upon storage at RT for 6 hrs and $2 \mathrm{wks}$ at $4^{\circ} \mathrm{C}$,however sufficient to support haemostasis

*Bacterial culture showed no growth and was similar to the study conducted by The Australian \& New Zealand Society of Blood Transfusion Limited. ${ }^{5}$

\section{Discussion}

The use of plasma and its products has evolved over a period of four decades and has increased manifold. This trend may be attributable to multiple factors, possibly including decreased availability of whole blood due to widespread acceptance of the concept of component therapy.

FFP contains the labile as well as stable components of the coagulation, fibrinolytic and complement systems; the proteins that maintain oncotic pressure and modulate immunity; and other proteins that have diverse activities. At present, well-defined indications exist for the use of FFP in single or multiple coagulation deficiencies. In the present study, fibrinogen and factor VIII levels were assessed, as they are representative of stable and labile factors respectively.

In the present study, PT and APTT in Group-1 on day 0 was in concordance with the study conducted by HT Naghadeh et al. ${ }^{8}$ The Prothrombin time on the last week of $12^{\text {th }}$ month was maintained within normal limits. By extending the storage shelf life to 18 months, there was statistically significant increase in prothrombin time which indirectly indicated decrease in extrinsic pathway coagulation factors. PT and APTT in Group-2 on day 0 , first week of $12^{\text {th }}$ month and last 
week of $12^{\text {th }}$ month on refrozen thawed plasma were in normal limits sufficient to support normal hemostasis. This was in concordance with the studies conducted by Lamboo et $\mathrm{al}^{7}$ and Dzik et al. ${ }^{9}$

In our study, fibrinogen level in Group-1 on day 0 was in concordance with the DGHS Standards. ${ }^{1}$ The fibrinogen level on the last week of $12^{\text {th }}$ month was maintained within normal limits. By extending the storage shelf life to 18 months, there was statistically significant decrease in fibrinogen level. Fibrinogen level in Group-2 on day 0 , first week of $12^{\text {th }}$ month and last week of $12^{\text {th }}$ month on refrozen thawed plasma were in normal limits sufficient to support normal hemostasis. This was in concordance with the studies conducted by Ofira Ben-Tal et $\mathrm{al}^{6}{ }^{6}$ Lamboo et $\mathrm{al}^{7}$ and Dzik et al. ${ }^{9}$

In our study, factor VIII level in Group- 1 on day 0 was in concordance with the DGHS Standards, ${ }^{1}$ Council of Europe standards, ${ }^{4}$ WHO criteria ${ }^{3}$ and study conducted by and HT Naghadeh et al. ${ }^{8}$ Factor VIII level on the last week of $12^{\text {th }}$ month was maintained within normal limits. By extending the storage shelf life to 18 months, there was statistically significant decrease in factor VIII level. Factor VIII level in Group-2 on day 0, first week of $12^{\text {th }}$ month and last week of $12^{\text {th }}$ month on refrozen thawed plasma were in normal limits sufficient to support normal hemostasis. There was a slight decrease in factor VIII level in the last week of $12^{\text {th }}$ month but it was not statistically significant. This was in concordance with the study conducted by Dzik et al. ${ }^{9}$

\section{Conclusion}

The present study suggests that the quality of fresh frozen plasma in a consecutive scheduled time within fixed shelf life and storage temperature $\left(-30^{\circ} \mathrm{C}\right.$ for 12 months) revealed adherence to various quality parameters but on extended storage period $\left(-30^{\circ} \mathrm{C}\right.$ for 18 months) showed non-compliance to the standardized quality control. Hence, extension of the shelf life of fresh frozen plasma stored at $-30^{\circ} \mathrm{C}$ from 12 months to 18 months would not be possible. However, Fresh Frozen Plasma can be stored up to 7 years at $-65^{\circ} \mathrm{C}$ without losing its potency. Our study also revealed that the refrozen (within 12 hours) thawed plasma complied with all quality parameters and hence this precious blood component should not be discarded, if for some reasons once thawed plasma is not used. These refrozen thawed units add up to the inventory and hence, useful for the society. However, further detailed study is required with regard to the duration and temperature in which these thawed plasma can be kept before refreezing so that the component retains its potency.

\section{References}

1. Directorate General of Health Services, Transfusion Medicine Technical Manual, second edition, 2003, page 352-354.

2. Technical Manual American Association of Blood Banks, $17^{\text {th }}$ edition AABB, page 1-20,217-221.

3. World Health Organization Handbook on the Clinical use of Blood in Medicine, Obstetrics, Paediatrics, Surgery \& Anaesthesia, Trauma \& Burns, 2002: Page 88. http://www.who.int/bloodsafety/clinical_use/en/Manual_ EN.pdf

4. Directorate for the Quality of Medicines \& Health Care of the Council of Europe (EDQM). Guide to the preparation, use and quality assurance of blood components. Recommendation No. R (95) 15, 16th ed. Strasbourg, France: Council of Europe Publishing, 2010, page 314.

http://www.centronazionalesangue.it/sites/default/files/gu ida_edqm_16_edizione.pdf

5. The Australian \& New Zealand Society of Blood Transfusion Ltd, Royal college of Nursing Australia, Extended life plasma: A framework for preparation, storage and use. $2^{\text {nd }}$ edition, 2013, page 9. (http://www.anzsbt.org.au/downloads/ELP_Printer_Frien dly_Corrected_Sept2013.pdf)

6. Ofira Ben-Tal et al. Vitamin K-dependent coagulation factors and fibrinogen levels in FFP remain stable upon repeated freezing and thawing. Transfusion. 2003;43(7):873-877.

7. M. Lamboo, D. C. W. Poland, et al. Coagulation parameters of thawed fresh-frozen plasma during storage at different temperatures. Transfusion Medicine.2007;17(3):182-186.

8. Hossin Timori Naghadeh et al. Coagulation factors V, VIII, and $\mathrm{X}$, prothrombin time and activated partial thromboplastin time test results in thawed plasma stored at $1-6^{\circ} \mathrm{C}$ for 5 days. Blood Transfus. 2011 January; 9(1):95-98.

9. Dzik WH; Riibner MA; Linehan SK et al. Refreezing previously thawed fresh-frozen plasma. Stability of coagulation factors V and VIII: C Transfusion.1989; 29(7):600-604. 